\title{
Determination of Heterodera glycines Virulence Phenotypes Occurring in South Dakota
}

K. Acharya, C. Tande, and E. Byamukama, Agronomy, Horticulture, and Plant Science Department, South Dakota State University, Brookings, SD 57007

\begin{abstract}
Acharya, K., Tande, C., and Byamukama, E. 2016. Determination of Heterodera glycines virulence phenotypes occurring in South Dakota. Plant Dis. 100:2281-2286.

The soybean cyst nematode (SCN), Heterodera glycines, is the most important yield-limiting pathogen of soybean in the United States. In South Dakota, SCN has been found in 29 counties, as of 2016, and continues to spread. Determining the virulence phenotypes (HG types) of the SCN populations can reveal the diversity of the SCN populations and the sources of resistance that would be most effective for SCN management. To determine the HG types prevalent in South Dakota, 250 soil samples were collected from at least three arbitrarily selected fields in each of the 28 counties with fields previously found to be infested with SCN. SCN was detected in 82 fields (33\%), and combined egg and juvenile counts ranged from 200 to 65,200 per $100 \mathrm{~cm}^{3}$ of soil. Eggs and juveniles were extracted from each soil sample and were used to infest seven SCN HG type test indicator soybean lines and 'Williams 82 ' as the susceptible check. A female index (FI) was calculated based on the number of females found on each

indicator line relative to those on the susceptible check. A FI equal to or greater than $10 \%$ in any line was assigned as that HG type. Out of $73 \mathrm{SCN}$ populations for which HG type tests were done, $63 \%$ had FI $\geq 10 \%$ on PI 548316 (indicator line \#7), $25 \%$ on PI 88788 (\#2), $19 \%$ on PI 209332 (\#5), $7 \%$ on PI 548402 (\#1), $4 \%$ on PI 90736 (\#3), and 4\% on PI 89722 (\#6). None of the SCN populations had FI $\geq 10 \%$ on PI 437654 (indicator line \#4). The most prevalent HG types were $0,2.5 .7$, and 7 . These accounted for $81 \%$ of all the HG types determined for the samples tested. HG types with $\geq 10 \%$ reproduction on indicator lines PI 88788, PI 209332, and PI 548317 were most prevalent in the soil samples tested, suggesting that the use of these sources of resistance for developing SCN resistant cultivars should be avoided. For sustainable SCN management, use of resistant cultivars should be rotated with nonhost crops and cultivars with different sources of resistance.
\end{abstract}

Soybean [Glycine max L. (Merr.)] is the most important leguminous crop and is ranked second after corn in terms of production in South Dakota and in the United States (NASS 2015). Soybean production is limited by different abiotic and biotic factors. Abiotic factors include low temperature, salt toxicity, water stress, nutritional deficiency, and biotic factors include weeds, insect pests, soybean cyst nematode (SCN), and diseases (Hartman et al. 2011). Of the biotic factors, SCN is the most limiting factor for soybean production in the United States (Koenning and Wrather 2010; Wrather and Koenning 2009).

The soybean cyst nematode, Heterodera glycines (Ichinohe 1955) is an obligate, sedentary endoparasitic nematode that infects soybean roots. It was first discovered in northeast China in 1899 (Li et al. 2011b) and identified in Japan in 1915, in Korea in 1936, in Manchuria in 1938, and in the United States in 1954 in North Carolina (Riggs 1977; Winstead et al. 1955). SCN is thought to have been inadvertently introduced into the U.S. with the Rhizobia inoculum from China in the first half of the 19th century (Noel 1986). SCN has now been detected in $90 \%$ of the soybean producing states (Tylka and Marett 2014) and was first detected in South Dakota in 1995 in Union county (Smolik et al. 1996).

The extent of yield loss caused by SCN depends upon the level of infestation, environmental factors, and the cultivar planted. SCN can cause yield loss of up to $30 \%$ without showing any visible symptoms in soybeans (Wang et al. 2003). Yield loss of up to 75\% in heavily infested fields is not uncommon (Wang et al. 2003; Young 1996). Yield loss can even be higher if SCN infection is associated with fungal pathogens such as Fusarium spp. (Xing and Westphal 2006).

Corresponding author: E. Byamukama,

Email: emmanuel.byamukama@sdstate.edu

Accepted for publication 8 July 2016.

http://dx.doi.org/10.1094/PDIS-04-16-0572-RE

(C) 2016 The American Phytopathological Society
Different practices have been used for SCN management, such as host resistance, chemical control, cultural methods and biological control (Auwal et al. 2014; Chen and Liu 2005; Concibido et al. 2004; Conley et al. 2011; Grabau 2013; Li et al. 2011a). Currently, growing resistant soybean cultivars and nonhost crops in rotation have proven to be the most effective, sustainable, and affordable methods of SCN management (Niblack et al. 2003; Oyekanmi and Fawole 2010; Schmitt et al. 2004). Recently, a few seed treatments have been introduced on the market that show some reduction of SCN population density in the soil (De Bruin and Pedersen 2008; Frye 2009; Grabau 2013; Wu et al. 2014).

There are many SCN resistant soybean cultivars available in the United States, but more than $90 \%$ of the resistant cultivars have been derived from the resistance source PI 88788 (Concibido et al. 2004; Schmitt et al. 2004; Shannon et al. 2004). Continued planting of varieties with the same $\mathrm{SCN}$ resistance genes can result in SCN populations that are adapted to these sources of resistance (Niblack 2005; Tylka and Mullaney 2015). Several research reports suggested that commonly used resistance source PI 88788 is being overcome by SCN in different states such as Kansas (Rzodkiewicz 2010), Kentucky (Hershman et al. 2008), Missouri (Mitchum et al. 2007), Minnesota (Zheng et al. 2006), Wisconsin, and other states (MacGuidwin 2012). Knowledge of the occurrence and distribution of virulent phenotypes (Heterodera glycines [HG] types) can provide valuable information regarding sustainable and effective use of resistant cultivars (Conley et al. 2011).

Knowledge of SCN diversity adapted to specific areas is important for SCN management. Characterization of SCN populations currently found in South Dakota is necessary for developing improved management strategies that incorporate the use of resistant cultivars derived from durable resistance sources. The analysis of soil samples submitted to the Plant Diagnostic Clinic, South Dakota State University show varying levels of infestation in soybean fields in South Dakota (Acharya et al. 2014). Many factors can lead to high SCN population densities in fields infested with SCN, including adaptation of the nematode populations to SCN resistant cultivars. Thus, the objective of this study was to determine levels of SCN infestation and HG types occurring in South Dakota. 


\section{Materials and Methods}

Soil sample collection. Soil sampling was conducted across 28 counties of South Dakota in which soybean cyst nematode had been detected through voluntary SCN testing at the South Dakota State University Plant Diagnostic Clinic. At least three soybean fields were

Table 1. Frequency and population densities of Heterodera glycines in the soil samples collected from different South Dakota counties during 2013 and 2014

\begin{tabular}{lcccc}
\hline & & & \multicolumn{2}{c}{ Eggs and juveniles } \\
\cline { 4 - 5 } County & samples $^{\mathbf{a}}$ & \% $^{\text {Positive }}{ }^{\mathbf{b}}$ & Maximum no. $^{\mathbf{c}}$ & Average no. $^{\mathbf{d}}$ \\
\hline Bon Homme & 8 & 37.5 & 19,900 & 10,267 \\
Brookings & 13 & 46.2 & 12,000 & 6,875 \\
Clay & 21 & 71.4 & 65,200 & 10,827 \\
Davison & 8 & 25.0 & 2,300 & 2,300 \\
Day & 5 & 20.0 & 10,000 & 10,000 \\
Deuel & 10 & 50.0 & 16,850 & 4,850 \\
Grant & 10 & 20.0 & 6,550 & 7,425 \\
Lake & 3 & 33.3 & 350 & 350 \\
Lincoln & 14 & 64.3 & 8,800 & 2,711 \\
McCook & 8 & 25.0 & 7,600 & 4,175 \\
Minnehaha & 8 & 50.0 & 1,100 & 738 \\
Moody & 12 & 50.0 & 28,600 & 17,250 \\
Roberts & 8 & 25.0 & 23,750 & 12,775 \\
Turner & 15 & 66.7 & 7,100 & 2,920 \\
Union & 12 & 84.6 & 50,000 & 15,042 \\
Yankton & 8 & 37.5 & 1,600 & 1,233 \\
\hline
\end{tabular}

a Total number of soil samples collected in a county.

b Percentage of samples positive for $H$. glycines.

c Maximum number of $H$. glycines eggs per $100 \mathrm{~cm}^{3}$ of soil.

${ }^{d}$ Average number of eggs and juveniles per $100 \mathrm{~cm}^{3}$ of soil (four replications) in positive soil samples from each county. arbitrarily selected from each of the 28 counties positive for SCN. In each field, up to $8.8 \times 10^{3} \mathrm{~cm}^{3}$ of soil was collected from field entrances, low spot areas, and along fence lines to obtain a representative soil sample that was most likely to have SCN. Soil was put into a plastic bag and labeled with the field number and collection date, then kept in the cooler before transportation and storage in the cold room at $4^{\circ} \mathrm{C}$ until $\mathrm{SCN}$ extraction was done. Each soil sample was manually mixed well and $100 \mathrm{~cm}^{3}$ of soil was taken for extraction of cysts using mechanical elutriation (Byrd et al. 1976). Extraction of eggs and juveniles from cysts was done by following the procedures as described by Faghihi and Ferris (2000). For samples with a sufficient number of eggs and juveniles $\left(>10,000 / 100 \mathrm{~cm}^{3}\right)$, extracted SCN eggs and juveniles (J2) were used for $H$. glycines typing. Samples with less than the required population density $(<10,000)$ were increased by inoculating the susceptible cultivar 'Williams 82' in the greenhouse, before performing HG type testing.

HG type determination. To determine HG types, indicator lines PI 548402 ('Peking', indicator \#1), PI 88788 (\#2), PI 90763 (\#3), PI 437654(\#4), PI 209332 (\#5), PI 89772 (\#6), PI 548316 ('Cloud', \#7), and a susceptible check ('Williams 82') were used (Niblack et al. 2002). Two seeds of each indicator line were directly planted into the cone-tainer $(3.8-\mathrm{cm}$ diameter and $21-\mathrm{cm}$ high, Stuewe and Sons, Inc., Tangent OR) filled with sterilized soil mixture (2 parts of sand and 1 part of soil by volume) and each line (indicator lines and susceptible check) was replicated four times for each SCN population. Infestation of the HG type indicator lines and the susceptible check with SCN was done at sowing following procedures by Niblack et al. (2002). After planting, the seven indicators and one susceptible check corresponding to SCN extracted from one soil sample were put in a 7.6-liter bucket filled with sand and then the bucket was placed in a water bath in the greenhouse. The water bath was maintained at $27-28^{\circ} \mathrm{C}$ and day length of $16 \mathrm{~h}$. Only one seedling per cone-tainer was maintained. After 35 days, the cone-tainers were taken out of

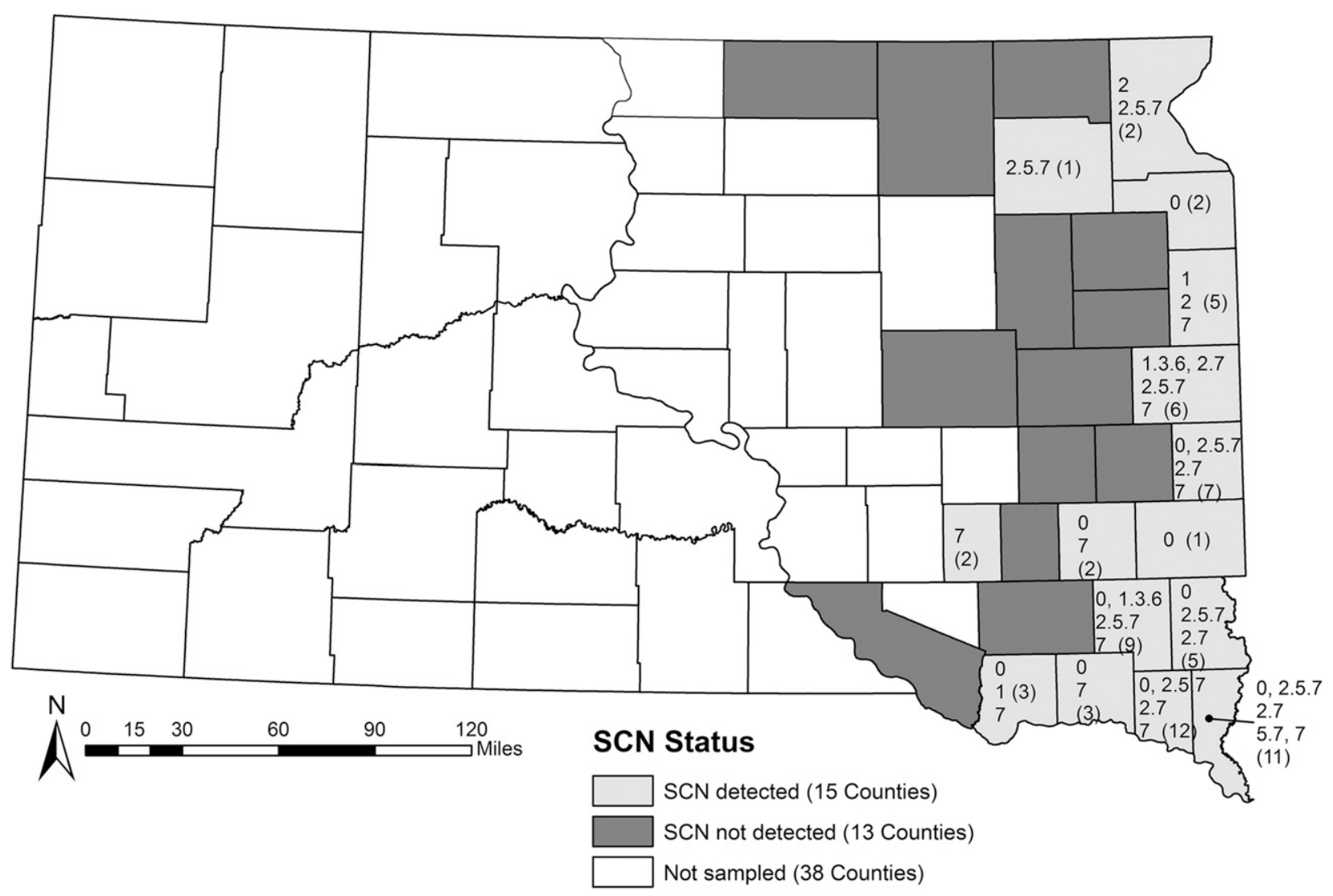

Fig. 1. Distribution of Heterodera glycines types found in soil samples collected in 2013 and 2014 in South Dakota. Within each county, the number in parentheses refers to the number of soil samples screened for HG types. 
Table 2. Heterodera glycines types in soil samples collected from different South Dakota counties during 2013 and 2014

\begin{tabular}{|c|c|c|c|c|c|c|c|c|c|}
\hline \multirow[b]{2}{*}{ County } & \multicolumn{7}{|c|}{ Female index $(\mathrm{FI})^{\mathbf{a}}$} & \multirow[b]{2}{*}{ Mean $^{b}$} & \multirow[b]{2}{*}{ HG type } \\
\hline & 1 (PI 548402) & 2 (PI 88788) & 3 (PI 90736) & 4 (PI 437654) & 5 (PI 209332) & 6 (PI 89722) & 7 (PI 548316) & & \\
\hline Bon Homme & 1.3 & 4 & 0.5 & 0.5 & 1.3 & 0.2 & 10.7 & 143 & 7 \\
\hline Bon Homme & 0.4 & 1.1 & 0 & 0.2 & 1.1 & 0.4 & 3.5 & 142 & 0 \\
\hline Bon Homme & 10.3 & 0.1 & 2.6 & 0 & 0 & 0.1 & 6.1 & 172 & 1 \\
\hline Brookings & 0 & 3.4 & 0 & 0 & 3.8 & 0.7 & 11.7 & 303 & 7 \\
\hline Brookings & 46.9 & 6.5 & 31 & 1.7 & 1.8 & 31.1 & 8.5 & 176 & 1.3 .6 \\
\hline Brookings & 47.8 & 4.1 & 35.4 & 1 & 4.8 & 61.4 & 3.7 & 269 & 1.3 .6 \\
\hline Brookings & 0 & 9.5 & 0.3 & 0 & 8.4 & 0 & 36 & 92 & $7 *$ \\
\hline Brookings & 1.7 & 11.1 & 1.9 & 0.1 & 11.9 & 1.9 & 26.1 & 189 & 2.5 .7 \\
\hline Brookings & 0 & 12.7 & 0.1 & 0.2 & 8.3 & 0.2 & 37.3 & 456 & 2.7 \\
\hline Brookings & 1.3 & 2.6 & 0 & 0 & 1.7 & 0 & 15.4 & 59 & $7 *$ \\
\hline Clay & 0.3 & 6.3 & 0 & 0 & 1.9 & 0.2 & 3.5 & 158 & 0 \\
\hline Clay & 3 & 0.4 & 0 & 0.2 & 1.5 & 1.5 & 4.9 & 118 & 0 \\
\hline Clay & 0.2 & 11.8 & 0.3 & 0 & 6.9 & 0.1 & 11.2 & 217 & 2.7 \\
\hline Clay & 0.1 & 5 & 0 & 0.1 & 6.9 & 0.1 & 15.4 & 423 & 7 \\
\hline Clay & 0.8 & 1.4 & 0.3 & 0.2 & 1.4 & 1.6 & 12.3 & 440 & 7 \\
\hline Clay & 0.3 & 0.4 & 0.9 & 0 & 0 & 0.2 & 1.8 & 279 & 0 \\
\hline Clay & 0.9 & 65.2 & 0 & 0 & 12.9 & 0 & 50.9 & 111 & 2.5 .7 \\
\hline Clay & 0.8 & 41.3 & 0.8 & 0.4 & 36 & 0 & 90.2 & 66 & $2.5 .7^{*}$ \\
\hline Clay & 0 & 0 & 0 & 0 & 0 & 0 & 0 & 96 & $0^{*}$ \\
\hline Clay & 2.1 & 1.7 & 1.5 & 0 & 5.4 & 1 & 8.7 & 353 & 0 \\
\hline Clay & 0 & 1.1 & 0 & 0 & 0.5 & 0.1 & 2.3 & 393 & 0 \\
\hline Clay & 1 & 5.4 & 2 & 0 & 9.3 & 0.5 & 7.4 & 233 & 0 \\
\hline Davison & 0 & 3.6 & 0 & 0 & 4 & 0.5 & 10.4 & 106 & 7 \\
\hline Davison & 0 & 7.5 & 0 & 0 & 8 & 0 & 13.4 & 97 & $7 *$ \\
\hline Day & 0.6 & 21 & 0 & 0 & 18.5 & 0.2 & 49 & 131 & 2.5 .7 \\
\hline Deuel & 0.7 & 7.3 & 0.2 & 0 & 9.5 & 0 & 17.9 & 134 & 7 \\
\hline Deuel & 3.3 & 5.2 & 0.9 & 0 & 3.5 & 2 & 13.1 & 114 & 7 \\
\hline Deuel & 0.2 & 13 & 0.9 & 0 & 4.7 & 0.2 & 6.7 & 112 & 2 \\
\hline Deuel & 19.5 & 2.5 & 8 & 0.5 & 0 & 3.5 & 1 & 50 & $1^{*}$ \\
\hline Deuel & 9.3 & 3.1 & 1.8 & 0.3 & 2.8 & 3.3 & 14.6 & 429 & 7 \\
\hline Grant & 0 & 0 & 0 & 0 & 0 & 0 & 4.5 & 73 & $0^{*}$ \\
\hline Grant & 0 & 4.3 & 0 & 0 & 1.2 & 0 & 8.8 & 226 & 0 \\
\hline Lincoln & 1 & 11.4 & 0.1 & 0 & 22.7 & 2.2 & 22.9 & 169 & 2.5 .7 \\
\hline Lincoln & 4.2 & 0.8 & 3.3 & 0.1 & 3.4 & 3.8 & 6.7 & 183 & 0 \\
\hline Lincoln & 1 & 17.8 & 0 & 0 & 21.4 & 0.3 & 23 & 329 & 2.5 .7 \\
\hline Lincoln & 0.8 & 2 & 0 & 0.4 & 2.4 & 0.6 & 13.8 & 125 & 7 \\
\hline Lincoln & 0.4 & 6.7 & 0.1 & 0.1 & 14.9 & 0 & 13.8 & 432 & 5.7 \\
\hline McCook & 0 & 2.3 & 0 & 0 & 0 & 0 & 5.3 & 296 & 0 \\
\hline McCook & 0 & 0.7 & 0 & 0 & 2 & 0.1 & 11 & 205 & 7 \\
\hline Minnehaha & 1.2 & 0.7 & 0 & 0 & 1.4 & 0 & 7.7 & 107 & 0 \\
\hline Moody & 4.8 & 11.2 & 0 & 0.2 & 13 & 0.1 & 18.8 & 154 & 2.5 .7 \\
\hline Moody & 3.6 & 2.2 & 0 & 0 & 10.3 & 0.7 & 10.3 & 192 & 5.7 \\
\hline Moody & 0.7 & 2.2 & 0 & 0 & 1.7 & 0 & 5 & 100 & 0 \\
\hline Moody & 0 & 1.5 & 0 & 0 & 2.5 & 0 & 19.4 & 188 & 7 \\
\hline Moody & 7.4 & 19.2 & 1.7 & 0.2 & 10.6 & 5.1 & 23.9 & 249 & 2.5 .7 \\
\hline Moody & 0 & 3.7 & 0 & 0 & 4.6 & 0 & 21.8 & 328 & 7 \\
\hline Moody & 0.1 & 10.1 & 0 & 0.1 & 4.6 & 0.1 & 12.9 & 404 & 2.7 \\
\hline Roberts & 2.6 & 5.6 & 0.3 & 0.4 & 4.6 & 0.2 & 19.8 & 244 & 7 \\
\hline Roberts & 3.6 & 10.3 & 3.1 & 0.2 & 10.5 & 2.1 & 10.1 & 221 & 2.5 .7 \\
\hline Turner & 1.2 & 1.7 & 0 & 0.5 & 6.5 & 0.2 & 13.2 & 100 & 7 \\
\hline Turner & 0.2 & 1 & 0 & 0 & 0 & 0.2 & 4.3 & 153 & 0 \\
\hline Turner & 0 & 8.5 & 0 & 0.1 & 5 & 0.1 & 15.3 & 237 & 7 \\
\hline Turner & 0 & 0.3 & 0 & 0 & 0.4 & 0.2 & 0.8 & 358 & 0 \\
\hline Turner & 0.5 & 17.7 & 0 & 0.1 & 12.4 & 0.1 & 24.3 & 343 & 2.5 .7 \\
\hline Turner & 0 & 0.7 & 0 & 0.1 & 0.7 & 0 & 2.6 & 246 & 0 \\
\hline Turner & 44.2 & 1.8 & 20.2 & 0 & 0.7 & 26.6 & 9 & 191 & 1.3 .6 \\
\hline Turner & 0 & 0 & 0.2 & 0 & 0.2 & 0 & 1 & 156 & 0 \\
\hline Turner & 7.9 & 4.5 & 0.5 & 0 & 2 & 0.2 & 13.8 & 401 & 7 \\
\hline Turner & 0.4 & 2.0 & 0 & 0 & 3.3 & 0.2 & 14.2 & 127 & 7 \\
\hline Union & 0.1 & 14.7 & 0 & 0 & 5.5 & 0.4 & 26.2 & 183 & 2.7 \\
\hline Union & 6.9 & 7 & 2.8 & 0.2 & 4.7 & 6.8 & 16.8 & 202 & 7 \\
\hline Union & 5.8 & 26.7 & 1.2 & 0.4 & 33.4 & 3.7 & 42.1 & 168 & 2.5 .7 \\
\hline Union & 1.3 & 1.7 & 0.2 & 0 & 0.8 & 0.2 & 1.9 & 159 & 0 \\
\hline Union & 8.8 & 21 & 1.3 & 0.2 & 12.9 & 0.3 & 26.2 & 250 & 2.5 .7 \\
\hline Union & 4.3 & 3.3 & 0.4 & 0.2 & 3.1 & 0.8 & 13.5 & 250 & 7 \\
\hline Union & 5.9 & 2.8 & 3.3 & 0.2 & 1.2 & 3.1 & 4.7 & 207 & 0 \\
\hline Union & 0.3 & 2.1 & 0.2 & 0 & 3.4 & 0.2 & 16.4 & 154 & 7 \\
\hline Union & 2.1 & 2.3 & 1.5 & 0.4 & 3.7 & 1.5 & 11.4 & 260 & 5.7 \\
\hline Union & 0.2 & 10.5 & 0 & 0 & 7.9 & 0 & 22.4 & 145 & 2.7 \\
\hline Union & 0.2 & 4.1 & 0 & 0 & 1.6 & 0 & 11.1 & 153 & 7 \\
\hline Yankton & 0.2 & 1.1 & 0 & 0 & 1.1 & 1.1 & 5.2 & 140 & 0 \\
\hline Yankton & 1.2 & 3.5 & 0 & 0 & 1.9 & 0.3 & 17.3 & 145 & 7 \\
\hline Yankton & 0.3 & 4.9 & 0.2 & 0 & 2.5 & 0.2 & 14.6 & 152 & 7 \\
\hline
\end{tabular}

${ }^{\text {a }} \mathrm{FI}=$ (mean number of females on indicator line/mean number of females on 'Williams 82 ') $\times 100$.

b Mean number of soybean cyst nematode females on 'Williams 82', the susceptible check.

c Asterisks (*) indicate HG types from tests in which the average number of cysts on 'Williams 82 ' was less than 100 (100 cysts on susceptible check is the desired level). 
the bucket and soaked in water for $15 \mathrm{~min}$ and the soybean plants were uprooted gently, placed on a testing sieve and sprayed with a strong stream of water to dislodge the SCN females (cysts) from the roots. SCN females were collected in a $250-\mu \mathrm{m}$-pore sieve nested under a $710-\mu \mathrm{m}$-pore sieve. Released females were counted for the determination of the FI. The number of females present on the roots of each of the indicator lines and the susceptible line were used for calculating FI. The FI for each line was calculated as follows: FI = (average number of cysts found on indicator line/average number of cysts found on susceptible line) $\times 100$.

An FI equal to or greater than $10 \%$ on any indicator line was assigned the number of the indicator line as the HG type.

Data analysis. Descriptive statistics for the FI data were obtained using SAS 9.3 (SAS Institute, Cary, NC). Pearson's product moment correlation was used for determining the association between the female indices for indicator lines. Average number of cysts from four replications was used for the calculation of FI for each soybean line.

\section{Results}

Of the 250 samples collected from the different counties previously known to have fields infested with SCN, 82 (33\%) were positive for SCN. These came from 16 of 28 counties sampled. Combined egg and juvenile counts from at least four replications of each of the soil samples ranged from 200 to 65,200 per $100 \mathrm{~cm}^{3}$ of soil (Table 1). Most of the SCN positive counties were from the southeastern part of the state (Fig. 1). The highest average SCN population density was found in Moody county, followed by Union and Roberts counties. Of the 82 samples that were positive for SCN, 73 samples had sufficient eggs and juveniles or were increased to obtain sufficient eggs and juveniles to conduct HG type tests. Nine samples did not have the required population density even after increasing on 'Williams 82' (mainly due to very low initial SCN population density in these soil samples) and were, hence, not included in the study.

Three SCN populations reproduced on PI 548402 (HG type indicator line \#1, 'Peking') with FI of 48, 47, and 44\%. These came from Turner and Brookings counties (Table 2). This line had only two other SCN populations with FI of $20 \%$ (from Deuel county) and

Table 3. Univariate analysis of female indices (FIs) of Heterodera glycines populations that had a FI $>10 \%$ on soybean indicator lines with resistance to H. glycines

\begin{tabular}{lccccc}
\hline $\begin{array}{l}\text { Soybean } \\
\text { indicator }\end{array}$ & & \multicolumn{4}{c}{ FI } \\
\cline { 3 - 6 } line $^{\mathbf{a}}$ & FI $>$ 10\% $^{\mathbf{b}}$ & $\begin{array}{c}\text { Minimum } \\
\text { observed }\end{array}$ & $\begin{array}{c}\text { Maximum } \\
\text { observed }\end{array}$ & Mean & $\begin{array}{r}\text { Standard } \\
\text { deviation }\end{array}$ \\
\hline 1 (PI 548402) & 6.8 & 10.3 & 47.8 & 33.7 & 17.5 \\
2 (PI 88788) & 24.7 & 10.1 & 65.2 & 19.2 & 13.8 \\
3 (PI 90736) & 4.1 & 20.2 & 35.4 & 28.8 & 7.8 \\
5 (PI 209332) & 19.1 & 10.3 & 36.0 & 17.2 & 8.4 \\
6 (PI 89722) & 4.1 & 26.6 & 61.4 & 39.7 & 19.0 \\
7 (PI 548316) & 63.0 & 10.1 & 90.2 & 20.8 & 14.3 \\
\hline
\end{tabular}

${ }^{a}$ None of the $H$. glycines populations inoculated to PI 437654 (indicator line \#4) had a FI $>10 \%$.

b Percentage of populations having $>10 \%$ FI.

Table 4. Frequencies of Heterodera glycines types in soil samples collected in 2013 and 2014 in South Dakota

\begin{tabular}{lcc}
\hline Type & No. of populations $^{\mathbf{a}}$ & Frequency (\%) \\
\hline 0 & 21 & 28.8 \\
1 & 2 & 2.7 \\
1.3 .6 & 3 & 4.1 \\
2 & 1 & 1.4 \\
2.7 & 5 & 6.8 \\
5.7 & 3 & 4.1 \\
7 & 26 & 35.6 \\
2.5 .7 & 12 & 16.4 \\
\hline
\end{tabular}

${ }^{a}$ Number of soybean cyst nematode populations (out of 73).
10\% (from Bon Homme county). PI 88788 (HG type indicator line \#2) had the second highest number of SCN populations with a FI $>10 \%$. The highest FI among SCN populations reared on PI 88788 was $65 \%$ and this soil sample came from Clay county. The rest of the SCN populations reared on PI 88788 (16 populations) had FI values between 10 and 27\%. PI 90736 (HG type indicator line \#3) had three SCN populations with $>10 \%$ FI (20, 31, and $35 \%)$. None of the SCN populations reared on PI 437654 (HG type indicator line \#4) had more than $10 \%$ FI, the highest FI on this indicator line was 1.7\%. On PI 209332 (HG type indicator line \#5), three SCN populations had an FI of 33, 23, and $21 \%$, and the rest of the SCN populations had a FI of $>10 \%$ but $<19 \%$. PI 89722 (HG type indicator line \#6) had three SCN populations with FI values of 61,31 (both from Brookings county), and $27 \%$ (from Turner county). PI 548316 (HG type indicator line \#7) had the highest number of SCN populations with FI $>10 \%$. The majority of the populations had FI values between 10 and 20\%. Four SCN populations had FI between 37 and $51 \%$ on this PI line.

Most of the $H$. glycines populations reproduced on all the indicator lines. However, PI 437654 (HG type indicator line \#4) had the lowest FI. Overall, $63 \%$ of SCN populations tested had FI $\geq 10 \%$ on PI $548316,25 \%$ on PI $88788,19 \%$ on PI $209332,7 \%$ on PI $548402,4 \%$ on PI 90736, and $4 \%$ on PI 89722 (Table 3). Among the SCN populations tested, a total of eight different HG types were found, i.e., $\mathrm{HG}$ type $0,1,2,7,2.7,5.7,1.3 .6$, and 2.5.7 (Table 4). HG type 7 ( $\geq 10 \%$ FI on indicator line \#7) was predominant (36\%), followed by HG types 0 (29\%) and 2.5.7 (16\%). These HG types (7, 0, and 2.5.7) collectively accounted for $81 \%$ of $H$. glycines populations found in the soil samples tested (Tables 1 and 5). HG type 0 indicates $H$. glycines populations with $<10 \%$ FI on any indicator line, whereas HG type 2.5.7 indicates $H$. glycines populations that had $\geq 10 \% \mathrm{FI}$ on indicator lines 2, 5, and 7. The diversity of the $H$. glycines populations varied between and within the counties. Brookings, Clay, Turner, and Union counties had more diverse SCN populations than any of the other counties (Table 6).

HG type 7 was the most predominantly detected phenotype, followed by HG types 2 and 1 . Although several SCN populations had a FI $>10 \%$ on HG type indicator line \#5, these populations also had a FI $>10 \%$ on HG type indicator lines \#2 and \#7. Similarly, SCN populations that had a FI $>10 \%$ on HG type indicator line \#6 also had a FI $>10 \%$ on HG type indicator lines \#3 and \#1. There was also a tendency for HG type 2 to have a FI $>10 \%$ on one or both HG type indicator lines \#5 or \#7. A positive correlation $(P \leq 0.05)$ was found between the FIs of some soybean indicator lines used in the HG type experiment. Indicator lines PI 88788, PI 209332, and PI 548316 were correlated with each other, and PI 548402, PI 90736, and PI 89722 were also correlated among each other (Table 6).

Table 5. County-wise distribution of Heterodera glycines types in soil samples collected from different South Dakota counties in 2013 and 2014

\begin{tabular}{lcl}
\hline County & No. tested $^{\mathbf{a}}$ & \multicolumn{1}{c}{ HG types } \\
\hline Bon Homme & 3 & $0,1,7(3)$ \\
Brookings & 7 & $1.3 .6,2.5 .7,2.7,7(4)$ \\
Clay & 12 & $0,2.5 .7,2.7,7(4)$ \\
Davison & 2 & $7(1)$ \\
Day & 1 & $2.5 .7(1)$ \\
Deuel & 5 & $1,2,7(3)$ \\
Grants & 2 & $0(1)$ \\
Lincoln & 5 & $0,2.5 .7,5.7(3)$ \\
McCook & 2 & $0,7(2)$ \\
Minnehaha & 1 & $0(1)$ \\
Moody & 7 & $0,2.57,2.7,7(4)$ \\
Roberts & 2 & $7,2.5 .7(2)$ \\
Turner & 10 & $0,1.3 .6,2.5 .7,7(4)$ \\
Union & 11 & $0,2.5 .7,2.7,5.7,7(5)$ \\
Yankton & 3 & $0,7(2)$ \\
\hline
\end{tabular}

${ }^{a}$ Number of soybean cyst nematode populations tested.

${ }^{\mathrm{b}}$ The number in parentheses refers to the number of $H$. glycines populations found in that county. 
Table 6. Correlation coefficient among soybean indicator lines with resistance to Heterodera glycines based on female indices (FIs) ${ }^{\mathrm{a}}$ from 73 H. $g l y c i n e s$ populations collected in 2013 and 2014

\begin{tabular}{lcccc}
\hline Indicator line & PI 548402 & PI 88788 & PI 90736 & PI 437654 \\
\hline PI 88788 & $-0.049 \mathrm{~ns}^{\mathrm{b}}$ & & & PI 209332 \\
PI 90736 & $0.959 * *$ & $-00.057 \mathrm{~ns}$ & \\
PI 437654 & $0.683 * *$ & $0.045 \mathrm{~ns}$ & $0.73108 * *$ & $0.069 \mathrm{~ns}$ \\
PI 209332 & $-0.084 \mathrm{~ns}$ & $0.705 * *$ & $-0.088 \mathrm{~ns}$ & $0.645 * *$ \\
PI 89722 & $0.900 * *$ & $-0.049 \mathrm{~ns}$ & $0.958 * *$ & $-0.05287 \mathrm{~ns}$ \\
PI 548316 & $-0.124 \mathrm{~ns}$ & $0.800 * *$ & $-0.137 \mathrm{~ns}$ & $0.796 * *$ \\
\hline
\end{tabular}

${ }^{\text {a }} \mathrm{FI}=$ (mean number of females on indicator line/mean number of females on 'Williams 82 ') $\times 100$.

${ }^{\mathrm{b}} \mathrm{ns}=$ not significant, $P>0.05 ; * *=P<0.001$.

\section{Discussion}

This study investigated the occurrence and distribution of $\mathrm{HG}$ types in the major soybean growing counties in South Dakota. Our results showed that SCN populations in soil samples collected in 2013 and 2014 had a total of eight different HG types, namely 0 , $1,2,7,2.7,5.7,1.3 .6$, and 2.5.7. HG types $0,2.5 .7$, and 7 were the most prevalent among the different HG types, suggesting that most of the SCN populations in the collected samples are virulent on PI 548316 ('Cloud', \#7), PI 88788 (\#2), and PI 209332 (\#5). Similar results were observed in Minnesota and Kentucky, where PI 548316 (\#7) was found to be most supportive for SCN reproduction. However, in Missouri and Kansas, HG type 2 (virulent on PI 88788) was most prevalent compared with other HG types (Hershman et al. 2008; Mitchum et al. 2007; Niblack et al. 2003; Rzodkiewicz 2010; Zheng et al. 2006). These results might suggest that some of the SCN populations in South Dakota are adapted to the commonly used SCN resistance source PI 88788 (\#2).

The frequencies of virulence phenotypes varied among the counties. SCN populations in some counties, such as Brookings, Turner, Union, and Clay, had more than three HG types detected. This may be partly due to a longer history of SCN infestation in these counties. Moreover, these counties may be planting resistant cultivars, hence, are likely to have higher SCN diversity as the nematode adapts to the SCN resistant cultivars (Kim et al. 1997).

We observed a significant correlation for FI between HG type indicator lines \#1 (PI 548402), \#3 (PI 90763), and \#6 (PI 89772). Also, significant correlation was observed between HG type indicator lines \#2 (PI 88788), \#5 (PI 209332), and \#7 (PI 89772). Similar results have been reported for two HG types, 1.3.6 and 2.5.7 (Colgrove and Niblack 2008). This implies that future breeding efforts should consider sources of resistances other than PI 209332 and PI 89772, because SCN populations adapting to PI 88788 will also most likely adapt to resistance from PI 209332 and PI 89772.

The available resistance sources for SCN are categorized into two groups, 'Peking' and PI 88788, based on their different resistance response (Colgrove and Niblack 2008; Kim et al. 1987). HG type indicator lines \# 3 (PI 90763) and \#6 (PI 89772) are considered part of the 'Peking' group, and their resistance induces early plant tissue response resulting in necrosis. HG type indicator lines \#2 (PI 88788), \#5 (PI 209332), and \#7 (PI 548316) are considered as PI 88788 group, and their resistance induces slower nuclear degradation of plant cells at the nematode feeding site (Colgrove and Niblack 2008: Kim et al. 1987). These groups indicate the risk of using a similar type of resistance source. Rotating within sources of resistance may delay the adaptation of SCN on these lines.

All the indicator lines showed some level of SCN adaptation, except PI 437654 (\#4), which was the indicator line that showed the best resistance to all the populations of SCN tested in this study. Due to the high level of resistance to most of the populations of SCN in the United States, PI 437654 (\#4) was used to develop resistant cultivar Hartwig (Anand 1992). However, SCN populations adapted to the resistant varieties derived from the resistance source PI 437654 (\#4) after a few generations in greenhouse studies (Colgrove and Niblack 2008). This underscores the need for an integrated approach to effectively manage SCN, as no one method can sustainably control SCN populations within a field.
Considering the frequency of $H$. glycines adapted on soybean indicator lines, PI 548316 ('Cloud', \#7) may not be preferred for breeding for SCN resistance because of higher SCN adaptability (more than $63 \%$ FI). PI 88788 (\#2) and 'Peking' (\#1) had 25 and 7\%, respectively, of the SCN populations tested with $\mathrm{FI} \geq 10 \%$, indicating a good level of resistance to most $\mathrm{SCN}$ populations tested. While these sources of resistance can still be used in SCN management, rotation with a nonhost crop and rotation between the different $\mathrm{SCN}$-resistant cultivars that have been derived from different resistance sources is highly recommended.

\section{Acknowledgments}

We thank the South Dakota Soybean Research and Promotion Council (SDSRPC) for funding this study. We are grateful to G. L. Tylka for all the assistance in this study. We also thank F. Mathew, K. Ruden, G. Redenius, E. Nayebare, D. Yabwalo, and J. Tande for their help during the course of the study. The views expressed in this study are not necessarily those of SDSRPC.

\section{Literature Cited}

Acharya, K., Byamukama, E., and Tande, C. 2014. The status of soybean cyst nematode, Heterodera glycines, in South Dakota. Phytopathology 104:S3.3. http://dx.doi.org/10.1094/PHYTO-104-11-S3.1

Anand, S. 1992. Registration of 'Hartwig'soybean. Crop Sci. 32:1069-1070.

Auwal, H. M., Wang, H., Li, L., Kakar, K. U., and Zheng, J. 2014. Utilization of plant materials for control of soybean cyst nematode. Soil Plant Sci. 64:392-397.

Byrd, D., Jr., Barker, K., Ferris, H., Nusbaum, C., Griffin, W., Small, R., and Stone, C. A. 1976. Two semi-automatic elutriators for extracting nematodes and certain fungi from soil. J. Nematol. 8:206-212.

Chen, S., and Liu, X. 2005. Control of the soybean cyst nematode by the fungi Hirsutella rhossiliensis and Hirsutella minnesotensis in greenhouse studies. Biol. Control 32:208-219.

Colgrove, A., and Niblack, T. 2008. Correlation of female indices from virulence assays on inbred lines and field populations of Heterodera glycines. J. Nematol. 40:39-45.

Concibido, V. C., Diers, B. W., and Arelli, P. R. 2004. A decade of QTL mapping for cyst nematode resistance in soybean. Crop Sci. 44:1121-1131.

Conley, S., Gaska, J., Pedersen, P., and Esker, P. 2011. Soybean yield and Heterodera glycines response to rotation, tillage, and genetic resistance. Agron. J. 103:1604-1609.

De Bruin, J. L., and Pedersen, P. 2008. Soybean cultivar and planting date response to soil fumigation. Agron. J. 100:965-970.

Faghihi, J., and Ferris, J. 2000. An efficient new device to release eggs from Heterodera glycines. J. Nematol. 32:411-413.

Frye, J. W. 2009. Efficacy of novel nematicide seed treatments for the control of Heterodera glycines in soybean production. M.S. thesis, North Carolina State University, Charlotte, NC.

Grabau, Z. 2013. Management strategies for control of soybean cyst nematode and their effect on the nematode community. M.S. thesis. University of Minnesota, Minneapolis, MN.

Hartman, G. L., West, E. D., and Herman, T. K. 2011. Crops that feed the world. Soybean worldwide production, use, and constraints caused by pathogens and pests. Food Secur. 3:5-17.

Hershman, D., Heinz, R., and Kennedy, B. 2008. Soybean cyst nematode, Heterodera glycines, populations adapting to resistant soybean cultivars in Kentucky. Plant Dis. 92:1475.

Ichinohe, M. 1955. Studies on the morphology and ecology of the soybean cyst nematode, Heterodera glycines, in Japan. Report of the Hokkaido National Agricultural Experimental Station, No. 48:59-64.

Kim, D., Riggs, R., Robbins, R., and Rakes, L. 1997. Distribution of races of Heterodera glycines in the central United States. J. Nematol. 29:173-179.

Kim, Y. H., Riggs, R. D., and Kim, K. S. 1987. Structural Changes Associated with Resistance of Soybean to Heterodera glycines. J. Nematol. 19:177-187.

Koenning, S. R., and Wrather, J. A. 2010. Suppression of soybean yield potential in the continental United States by plant diseases from 2006 to 2009. Plant Health Prog. Published online. doi:10.1094/PHP-2010-1122-01-RS 
Li, J., Todd, T. C., Lee, J., and Trick, H. N. 2011a. Biotechnological application of functional genomics towards plant-parasitic nematode control. Plant Biotechnol. J. 9:936-944.

Li, Y. H., Qi, X. T., Chang, R., and Qiu, L. J. 2011b. Evaluation and utilization of soybean germplasm for resistance to cyst nematode in China. Pages 373-396 in: Soybean Molecular Aspects of Breeding. A. Sudaric, ed. Intech Publishers, Rijeka, Croatia.

MacGuidwin, A. 2012. Distribution of SCN HG types in Wisconsin. 2011, Page 107 in: Proc. of the 2012 Wisconsin Crop Management Conference, Vol. 51. University of Wisconsin-Extension, Madison, WI. Published online. http:// extension.soils.wisc.edu/wp-content/uploads/sites/47/2014/02/2012_wcmc_proc. pdf

Mitchum, M. G., Wrather, J. A., Heinz, R. D., Shannon, J. G., and Danekas, G. 2007. Variability in distribution and virulence phenotypes of Heterodera glycines in Missouri during 2005. Plant Dis. 91:1473-1476.

NASS. 2015. South Dakota Agricultural Bulletin no. 75. South Dakota Department of Agriculture, Pierre, SD. Published online. http://sdda.sd.gov/office-of-thesecretary/publications/pdf/2015.sd.ag.bulletin.pdf

Niblack, T. 2005. Soybean cyst nematode management reconsidered. Plant Dis. 89:1020-1026.

Niblack, T., Arelli, P., Noel, G., Opperman, C., Orf, J., Schmitt, D., Shannon, J., and Tylka, G. 2002. A revised classification scheme for genetically diverse populations of Heterodera glycines. J. Nematol. 34:279-288.

Niblack, T., Wrather, J., Heinz, R., and Donald, P. 2003. Distribution and virulence phenotypes of Heterodera glycines in Missouri. Plant Dis. 87: 929-932.

Noel, G. R. 1986. The soybean cyst nematode. Pages 257-268 in: Cyst Nematodes. F. Lamberti, C. E. Taylor, eds. Springer US, New York.

Oyekanmi, E. O., and Fawole, B. 2010. Nematodes of soybean and their management. Pages 325-341 in: The Soybean: Botany, Production and Uses. G. Singh, ed. CABI, Rawalpindi, Pakistan.

Riggs, R. 1977. Worldwide distribution of soybean-cyst nematode and its economic importance. J. Nematol. 9:34-39.
Rzodkiewicz, P. A. 2010. Characterization of soybean cyst nematode diversity in Kansas. M.S. thesis. Kansas State University, Manhattan, KS.

Schmitt, D. P., Wrather, J. A., and Riggs, R. D. 2004. Biology and Management of Soybean Cyst Nematode, 2nd Ed. Walsworth Publishing Company, Marceline, MO.

Shannon, J. G., Arelli, P. R., and Young, L. D. 2004. Breeding for soybean cyst nematode resistance. Pages 155-180 in: Biology and Management of Soybean Cyst Nematode. R. D. Riggs, and J. A. Wrather, eds. American Phytopathological Society, St. Paul, MN

Smolik, J., Jones, J., Gallenberg, D., and Gille, J. 1996. First report of Heterodera glycines on soybean in South Dakota. Plant Dis. 80:224.

Tylka, G. L., and Marett, C. C. 2014. Distribution of the soybean cyst nematode, Heterodera glycines, in the United States and Canada: 1954 to 2014. Plant Health Prog. Published online. doi:10.1094/PHP-BR-14-0006

Tylka, G. L., and Mullaney, M. P. 2015. Soybean cyst nematode-resistant soybean varieties for Iowa. Iowa State University Extension, Ames, IA. Published online. http://www.plantpath.iastate.edu/tylkalab/files/page/files/2015\%20ISU\% 20SCN-Resistant $\% 20$ Variety\%20Trials.pdf.

Wang, J., Niblack, T., Tremain, J., Wiebold, W., Tylka, G., Marett, C., Noel, G., Myers, O., and Schmidt, M. 2003. Soybean cyst nematode reduces soybean yield without causing obvious aboveground symptoms. Plant Dis. 87:623-628.

Winstead, N., Skotland, C., and Sasser, J. 1955. Soybean cyst nematode in North Carolina. Plant Dis. Report. 39:9-11.

Wrather, J., and Koenning, S. 2009. Effects of diseases on soybean yields in the United States 1996 to 2007. Online. Plant Health Prog. Published online. doi: 10.1094/PHP-2009-0401-01-RS

Wu, H., Masler, E. P., Rogers, S. T., Chen, C., and Chitwood, D. J. 2014. Benzyl isothiocyanate affects development, hatching and reproduction of the soybean cyst nematode Heterodera glycines. Nematology 16:495-504.

Xing, L. J., and Westphal, A. 2006. Interaction of Fusarium solani f. sp. glycines and Heterodera glycines in sudden death syndrome of soybean. Phytopathology 96:763-770.

Young, L. 1996. Yield loss in soybean caused by Heterodera glycines. J. Nematol 28:604-607.

Zheng, J., Li, Y., and Chen, S. 2006. Characterization of the virulence phenotypes of Heterodera glycines in Minnesota. J. Nematol. 38:383-390. 